\title{
Pemaafan Dan Kemampuan Interaksi Sosial Pada Mahasiswa Program Studi Psikologi Islam Fakultas Dakwah Institut Agama Islam Negeri (IAIN) Salatiga Tahun 2018
}

\author{
Qurrotu Ayun \\ IAIN Salatiga, Jawa Tengah, Indonesia \\ qurrotuayu@yahoo.com
}

\begin{abstract}
Abstrak
Penelitian ini bertujuan untuk mengetahui sejauhmana hubungan antara tingkat pemaafan dengan kemampuan interaksi sosial pada mahasiswa. Responden dalam penelitian ini adalah 150 mahasiswa program studi psikologi islam, Fakultas Dakwah Institut Agama Islam Negeri Salatiga, dengan rentang usia 17-21 tahun. Hipotesis yang diajukan peneliti adalah adanya hubungan positif antara variabel pemaafan dan kemampuan interaksi sosial pada mahasiswa. Yang artinya, semakin tinggi tingkat pemaafan yang dimiliki oleh mahasiswa, maka semakin tinggi pula kemampuan interaksi sosialnya. Jenis data dalam penelitian adalah data nominal dan interval. Data yang diperoleh dalam penelitian dianalisis dengan menggunakan teknik analisis dan korelasi product moment dari Karl Pearson yang digunakan untuk melihat hubungan antar variabel. Hasil penelitian menunjukkan ada korelasi positif antara pemaafan dengan kemampuan interaksi sosial pada mahasiswa $(r=0,679)$ dan $\mathrm{p}<0,01$ ) dengan kontribusi variabel pemaafan pada kemampuan interaksi sosial sebesar $46 \%$. Analisis lain yang digunakan dalam penelitin ini adalah menggunakan analisis regresi untuk melihat ada tidaknya perbedaan tingkat pemaafan ditinjau dari jenis kelamin, serta demografi usia. Hasil analisis menunjukkan terdapat perbedaan aspek pemaafan ditinjau dari jenis kelamin dan demografi usia.
\end{abstract}

Kata Kunci : Pemaafan, interaksi sosial, mahasiswa 


\begin{abstract}
Forgiveness and Social Interaction Ability of Students of the Islamic Psychology Study Program, Faculty of Da'wah, Salatiga State Islamic Institute (IAIN) 2018. This study aims to determine the extent of the relationship between the level of forgiveness and the ability of social interaction in students. Respondents in this study were 150 students of Islamic psychology study program, the Da'wah Faculty of the Islamic State Institute of Salatiga, with an age range of 17-21 years. The hypothesis proposed by the researcher is that there is a positive relationship between forgiveness variables and the ability of social interaction in students. Which means, the higher the level of forgiveness owned by students, the higher the social interaction ability. The type of data in the study is nominal and interval data. The data obtained in the study were analyzed using Karl Pearson's product moment analysis and product moment correlation which was used to see the relationship between variables. The results showed that there was a positive correlation between forgiveness and the ability of social interaction in students $(r=0.679)$ and $p<0.01)$ with the contribution of forgiveness variables on social interaction ability by 46\%. Another analysis used in this study is to use regression analysis to see whether there is a difference in the level of forgiveness in terms of gender, and age demographics. The results of the analysis show that there are differences in aspects of forgiveness in terms of gender and age demographics.
\end{abstract}

Key Words : Forgiveness, Social Interaction, Students

\title{
A. Pendahuluan
}

Interaksi sosial merupakan tahapan dimana manusia memulai hubungan antara satu dengan lainnya. Manusia berinteraksi untuk dapat saling mengenal, memahami dan bekerjasama antara satu sama lain. Interaksi sosial juga mengantarkan manusia pada kondisi bahagia, senang, marah, sedih, bermakna, tersakiti hingga konflik (H. F. Nashori, 2008). Proses Interaksi sosial dialami oleh mahasiswa dalam menjalani aktivitas dan perannya di perguruan tinggi. Interaksi sosial dapat bersifat perseorangan atau kelompok. Dalam melakukan proses interaksi, seringkali mahasiswa merasakan adanya ketidaksepahaman antar individu yang dapat menyebabkan konflik sehingga berdampak pada buruknya relasi sosial di kalangan teman sebaya. 
Menurut Rostiana (1999), jika seseorang kurang terampil menjalin hubungan sosial maka konflik interpersonal akan mudah terjadi pada individu tersebut. Konflik interpersonal dirasa memiliki dampak paling signifikan bagi individu. Dampak buruk yang diterima individu dalam sebuah konflik interpersonal antara lain trauma, marah, benci, dendam, bersikap pasif, hilangnya kepercayaan dan semangat, tidak ingin bertemu (menghindar), cemas, khawatir, takut, stres, depresi dan sejenisnya (F. Nashori, 2012). Segala hal yang berhubungan dengan konflik terkait siapa, dimana, kapan, dan bagaimana ternyata memberikan dampak yang cukup signifikan terhadap perkembangan psikologis individu.

Walgito (2003) mengemukakan interaksi sosial adalah hubungan antara individu satu dengan individu lain, individu satu dapat mempengaruhi individu yang lain atau sebaliknya, sehingga terdapat hubungan yang saling timbal balik. Hubungan tersebut dapat terjadi antara individu dengan individu, individu dengan kelompok atau kelompok dengan kelompok. Adapun Basrowi (2005) mengemukakan interaksi sosial adalah hubungan dinamis yang mempertemukan orang dengan orang, kelompok dengan kelompok, maupun orang dengan kelompok manusia. Bentuknya tidak hanya bersifat kerjasama, tetapi juga berbentuk tindakan, persaingan, pertikaian dan sejenisnya.

Berdasarkan data hasil wawancara dengan mahasiswa program studi psikologi islam, diperoleh kasus-kasus sebagai berikut :

"saya merasa marah dan sakit hati terhadap ucapannya, saya mengira bahwa selama ini hubungan pertemanan antara saya dan dia baik-baik saja dan dia bisa memahami saya. Dari awal mula kami mendaftar pada jurusan yang sama dengan harapan saya mempunyai teman baik untuk bisa bersama-sama mengikuti kegiatan dikampus kami. Secara emosi saya merasakan marah, benci, dendam dan tidak ingin berhubungan lagi dengannya. Yang saya tidak habis pikir kenapa dia tidak mengkomunikasikan apa yang dia rasakan langsung kepada saya, tetapi malah koar-koar kepada orang lain sehingga teman-teman lain berpersepsi negatif terhadap saya. Sungguh saya merasa muak dan malas untuk bertemu dan berinteraksi dengan dia lagi" (Mahasiswi AZ, wanita 19 tahun) 
"saya memiliki kondisi yang membuat saya merasa punya masalah dalam hubungan pertemanan. Ada satu peristiwa masa kecil yang membuat saya marah dan merasa tidak berharga. Setiap saya melihat rekan-rekan saya berkumpul dan berdiskusi dan terkadang tertawa-tawa saya merasa itu ditujukan kepada saya dengan tujuan mengejek diri saya. Saya terkadang marah dengan diri saya, dan bertanya kenapa saya kok seperti ini. Hal tersebut membuat saya merasa lebih nyaman melakukan aktivitas sendiri daripada harus bersama-sama dengan teman"(mahasiswa GA,20 tahun)

"saya memiliki penyakit yang mengharuskan saya melakukan transfusi darah saat kondisi badan saya drop atau minimal 4 bulan sekali. Setiap selesai dilakukan transfusi tubuh saya harus beradaptasi dengan darah yang masuk ke tubuh. Saya merasakan lemas, sulit tidur dan kalau sudah tidur terkadang juga sulit bangun. Mengikuti perkuliahan dikampus adalah merupakan perjuangan luar biasa yang saya lakukan. Kondisi penyakit dan fisik saya membuat saya menjadi minder dan tidak percaya diri. Belum lagi teman-teman dikampus yang seolah-olah mengucilkan saya. Sebenarnya saya memiliki masalah yang cukup rumit dengan ayah saya. Saya masih ingat sejak kelas 4 SD saya sering sekali dipukul setiap kali ayah saya memiliki masalah. Saya merasa bahwa saya adalah pelampiasan kekesalannya. Selain itu saya juga msh ingat betul ketika SMP saya pernah di bully habis-habisan oleh temanteman karena ada yang melihat dan mengetahui penyakit saya. Saya dianggap menjijikkan dan tidak pantas untuk dijadikan teman. Saat itu saya merasa marah, kecewa, sedih, ingin pergi jauh dan merasa tidak berharga. Kekerasan fisik dan verbal yang saya terima membuat saya enggan sekali untuk berinteraksi dengan ayah maupun teman-teman di kampus. Lebih baik saya sendirian daripda pada akhirnya nanti saya menerima perlakukan seperti masa SMP dulu. (mahasiswi, NY, 18 tahun).

Kasus lain yang dimuat berdasarkan data dari media massa di Indonesia, sebuah berita dimuat dalam detik.com menyatakan bahwa seorang mahasiswa membunuh teman indekostnya karena merasa sakit hati. Tersangka berinisial $\mathrm{M}$ berusia (18) tahun tega membunuh S (42) tahun. Dari pengakuan $\mathrm{M}$, ia merasa sakit hati dan tersinggung dengan perkataan S karena dituduh mencuri (Detik.com, 2016).

Kasus-kasus diatas menunjukkan jika konflik yang dialami masing-masing individu baik dengan pelaku, diri sendiri, peristiwa dan situasi memberikan dampak emosi yang signifikan. Dari temuan di lapangan menunjukkan jika kegagalan hubungan interpersonal yang disebabkan karena sakit hati, marah, 
dendam, kecewa dapat menimbulkan tindak kekerasan bahkan kematian. Hasil wawancara dengan beberapa dosen pembimbing akademik mahasiswa juga menyebutkan banyak mahasiswa yang mengeluhkan kurang dapat menyelesaikan tugas dari dosen dengan maksimal dikarenakan permasalahan relasi sosial yang kurang menyenangkan, tidak terkomunikasikan informasi dari dosen dengan baik ke mereka serta adanya konflik internal antar mahasiswa.

\section{B. Pembahasan}

\section{Kemampuan Interaksi Sosial}

Kegiatan interaksi sosial mensyaratkan dua pokok terjadinya interaksi sosial, menurut pendapat Dayakisni dan Hudaniah (2009) menyatakan bahwa interaksi sosial tidak mungkin terjadi apabila tidak memenuhi dua syarat yaitu adanya kontak sosial dan komunikasi. Yang pertama adalah kontak sosial; kontak sosial dapat terjadi antara individu dengan individu, individu dengan kelompok, dan antara kelompok dengan kelompok. Menurut Abdulsyani (1994) "kontak sosial adalah hubungan antara satu orang atau lebih, melalui percakapan dengan saling mengerti tentang maksud dan tujuan masing-masing dalam kehidupan masyarakat". Kontak sosial dapat dibedakan menjadi dua macam yaitu kontak primer dan kontak sekunder. Kontak primer, terjadi apabila seseorang mengadakan hubungan secara langsung seperti : tatap muka, saling senyum, berjabat tangan, dan lain-lain. Sedangkan kontak sekunder, yaitu kontak tidak langsung atau memerlukan perantara seperti : menelpon dan berkirim surat. Apabila dicermati, baik dalam kontak primer maupun kontak sekunder terjadi hubungan timbal balik antara komunikator dan komunikan. Dalam percakapan tersebut agar kontak sosial dapat berjalan dengan baik, harus ada rasa saling pengertian dan kerjasama yang baik antara komunikator dengan komunikan. Dari penjelasan di atas terlihat ada tiga komponen pokok dalam kontak sosial, yaitu : (1) percakapan, (2) saling pengertian, (3) kerjasama antara komunikator dan komunikan. Ketiga komponen tersebut merupakan kemampuan interaksi sosial 
yang harus dimiliki oleh individu. Ketiga komponen pokok dalam kontak sosial itu akan dijadikan indikator dalam penyusunan instrumen yang akan digunakan oleh peneliti dalam penelitian ini. Yang kedua adalah adanya komunikasi; sementara komunikasi baik verbal maupun non verbal merupakan saluran untuk menyampaikan perasaan ataupun gagasan dan sekaligus sebagai media untuk dapat menafsirkan atau memahami pikiran atau perasaan orang lain.

Menurut De Vito dalam (Sugiyo, 2005) menyatakan bahwa "ciri - ciri komunikasi meliputi lima ciri yaitu : keterbukaan,empati, dukungan, rasa positif, dan kesamaan". Adapun penjelasannya sebagai berikut :

1) Keterbukaan atau opennes

Komunikasi antar pribadi mempunyai ciri keterbukaan maksudnya adanya kesediaan kedua belah pihak untuk membuka diri, mereaksi kepada orang lain, merasakan pikiran dan perasaan orang lain. Keterbukaan ini sangat penting dalam komunikasi antarpribadi agar komunikasi menjadi lebih bermakna dan efektif. Keterbukaan ini berarti adanya niat dari masingmasing pihak yang dalam hal ini antara komunikator dan komunikan saling memahami dan membuka pribadi masing-masing.

2) Empati

Dalam komunikasi antarpribadi perlu ada empati dari komunikator, hal ini dapat dinyatakan bahwa komunikasi antarpribadi akan berlangsung secara kondusif apabila pihak komunikator menunjukkan rasa empati pada komunikan. Empati dapat diartikan sebagai menghayati perasaan orang lain atau turut merasakan apa yang dirasakan orang lain. Menurut Surya (Sugiyo, 2005) empati adalah sebagai suatu kesediaan untuk memahami orang lain secara paripurna baik yang nampak maupun yang terkandung, khususnya dalam aspek perasaan,pikiran, dan keinginan. Dengan berempati kita menempatkan diri dalam suasana perasaan, pikiran, dan keinginan orang lain sedekat mungkin. Secara psikologis apabila dalam komunikasi komunikator menunjukkan empati pada komunikan akan menunjang 
berkembangnya suasana hubungan yang didasari atas saling pengertian, penerimaan, dipahami, dan adanya kesamaan diri. Dukungan Dalam komunikasi antarpribadi perlu dimunculkan sikap memberi dukungan dari pihak komunikator agar komunikan mau berpartisipasi dalam kominikasi. De Vito (Sugiyo, 2005) secara tegas menyatakan keterbukaan dan empati tidak akan bertahan lama apabila tidak didukung oleh suasana yang mendukung. Hal ini berarti bahwa dalam komunikasi antarpribadi perlu adanya suasana yang mendukung atau memotivasi, lebih-lebih dari komunikator.

3) Rasa positif

Rasa positif dalam komunikasi antarpribadi ditunjukkan oleh sikap dari komunikator khususnya sikap positif. Sikap positif dalam hal ini berarti adanya kecenderungan bertindak pada diri komunikator untuk memberikan penilaian yang positif terhadap komunikan. Dalam komunikasi antarpribadi sikap positif ini ditunjukkan oleh sekurang-kurangnya dua aspek/ unsur yaitu: pertama, komunikasi antarpribadi hendaknya memberikan nilai positif dari komunikator. Maksud pernyataan ini yaitu apabila dalam komunikasi, komunikator menunjukkan sikap positif terhadap komunikan maka komunikan juga akan menunjukkan sikap positif. Sebaliknya jika komunikator menunjukkan sikap negatif maka komunikan juga akan bersikap negatif. Kedua,perasaan positif pada diri komunikator. Hal ini berarti bahwa situasi dalam komunikasi antarpribadi hendaknya menyenangkan. Apabila kondisi ini tidak muncul maka komunikasi akan terhambat dan bahkan akan terjadi pemutusan hubungan.

4) Kesamaan

Kesamaan menunjukkan kesetaraan antara komunikator dan komunikan. Dalam komunikasi antarpribadi kesetaraan ini merupakan ciri yang penting dalam keberlangsungan komunikasi dan bahkan keberhasilan komunikasi antarpribadi. Apabila dalam komunikasi antarpribadi komunikator merasa 
mempunyai derajat kedudukan yang lebih tinggi daripaad komunikan maka dampaknya akan ada jarak dan ini berakibat proses komunikasi akan terhambat. Namun apabila komunikator memposisikan dirinya sederajat dengan komunikan maka pihak komunikan akan merasa nyaman sehingga proses komunikasi akan berjalan dengan dengan baik dan lancar.

Interaksi sosial yang negatif ditandai dengan munculnya sebuah konflik. Menurut Deutsch (Dayakisni \& Hudaniah, 2009) konflik terjadi ketika ada ketidakselarasan dalam aktivitas-aktivitas. Ketidakselarasan tersebut bisa terjadi antara dua orang atau lebih dalam suatu kelompok Kegagalan interaksi sosial yang dialami oleh mahasiswa lebih banyak disebabkan karena rasa kecewa, sakit hati, marah, dan dendam sehingga yang pada akhirnya berdampak pada relasi interpersonal yang buruk, saling menyalahkan dan kurangnya kerjasama dalam tim.

\section{Pemaafan}

Burney dan Kromrey (2001) mengemukakan perlu adanya strategi manajemen kemarahan yang baik dan belajar mencari solusi positif sebagai alternatif bagi remaja untuk menghadapi suatu masalah. Hasil penelitian menunjukkan individu yang dapat memaafkan mengalami penurunan kemarahan, kecemasan dan depresi akibat kekerasan di masa kecil secara signifikan (Thompson et al., 2005). Selain itu menurut Worthington dan Scherer (2004) menyatakan bahwa pemaafan merupakan strategi emotion focused coping untuk meredakan stres, kesehatan yang baik, dukungan sosial, kualitas hubungan dan agama. Perilaku memaafkan dapat digunakan oleh remaja untuk bisa melepaskan semua beban penderitaan seperti stres, menyimpan dendam, beban pikiran dan perasaan sakit. Selesainya suatu konflik ditandai dengan adanya saling menerima dan memaafkan baik pada peristiwa, pelaku dan kondisi.

Berdasarkan penelitian Arif (2013) konflik interpersonal remaja adalah konflik yang sering dialami remaja dengan teman bermainnya. Remaja menilai lingkungan dan temannya berdasarkan keserasian atau kesamaan yang 
dimilikinya. Jika terdapat perbedaan, maka memicu timbulnya pengabaian dan kurangnya penerimaan. Selanjutnya, beberapa kesalahan yang dilakukan oleh individu seperti ketidaksetiaan, pengkhianatan, kebrutalan, dan agresivitas dapat memberikan luka dan korban jiwa yang sulit untuk dimaafkan. Hal ini menimbulkan frustrasi dikarenakan rasa kecewa yang kemudian dapat menyebabkan berbagai dampak negatif, salah satunya berperilaku agresif ingin membalas.

Penelitian lain yang dilakukan Luskin (F. Nashori, 2014) menyatakan bahwa individu yang memaafkan akan semakin jarang terlibat konflik. Oleh karena itu pemaafan merupakan salah satu cara dalam mencegah terjadinya konflik, pemaafan memberikan implikasi yang besar dalam hubungan jangka pendek dan jangka panjang (Fincham, Beach, \& Davila, 2004). Hal tersebut menerangkan bahwa memaafkan merupakan salah satu metode resolusi konflik yang efektif untuk menyelesaikan konflik secara beradab, baik konflik kelompok maupun interpersonal.

Penelitian yang dilakukan Gani (2011), menyebutkan bahwa tidak memaafkan berdampak memiliki gejala tekanan darah tinggi, stres, kemarahan mudah terpicu, tekanan jantung meninggi, menunjukkan gejala depresi, menunjukkan gejala kecemasan, merasa nyeri akut pada tubuh, hubungan dengan orang lain kurang akrab, sukar menjalin persahabatan, merasa diri hampa, dan tendensi pelarian pada minuman beralkohol dan obat-obatan. Begitu banyak dampak buruk jika tidak memaafkan. Oleh karenanya, memaafkan merupakan pola dan sikap positif untuk kesejahteraan yang baik bagi individu.

Enright, et al., serta The Human Development Study Group (Dayakisni \& Hudaniah, 2009) mendefinisikan pemaafan adalah suatu kesediaan individu (yang di sakiti/dilanggar) meninggalkan hak yang dimilikinya untuk membenci, menilai negatif dan berperilaku tidak peduli kepada orang lain yang telah berperilaku tidak adil, dan sebaliknya lebih mendukung kualitas tentang perasaan kasihan, 
kebaikan hati dan bahkan cinta yang semestinya tak diberikan kepada orang yang telah menyakitinya.

Exline dan Baumeister (Dayakisni \& Hudaniah, 2009) mendefinisikan pemaafan adalah pembatalan dari piutang oleh orang yang telah melukai atau berbuat salah. Sementara McCullough, et al. (1997) mendefinisikan pemaafan adalah sejumlah perubahan motivasional seseorang yang menjadi: (a) berkurangnya motivasi untuk membalas melawan pihak yang menyerangnya; (b) berkurangnya motivasi untuk mempertahankan keterpisahan dari penyerang; dan (c) meningkatnya motivasi dengan konsiliasi dan kemauan baik (goodwill) kepada penyerang, meskipun tindakan penyerang menyakitkan.

Enright (H. F. Nashori, 2008) mengungkapkan adanya empat fase untuk pemberian maaf. Pertama, fase pengungkapan (uncovering phase), yaitu ketika seseorang merasa sakit hati dan dendam. Kedua, fase keputusan (decision phase), yaitu orang tersebut mulai berpikir rasional dan memikirkan kemungkinan untuk memaafkan. Pada fase ini, orang belum dapat memberikan maaf sepenuhnya. Ketiga, fase tindakan (work phase), yaitu adanya tingkat pemikiran baru untuk secara aktif memberikan maaf kepada orang yang telah melukai hati. Keempat, fase pendalaman (outcome/deepening phase), yaitu internalisasi kebermaknaan dari proses memaafkan, ia akan memberi manfaat bagi dirinya sendiri, lingkungan dan juga semua orang.

Menurut Nashori (2014) pemaafan dibagi atas tiga dimensi yaitu (1) Dimensi Emosi. Beberapa indikator pemaafan dari dimensi emosi adalah (a) meninggalkan perasaan marah, benci, sakit hati. (b) Mampu mengontrol emosi saat diperlakukan tak menyenangkan. (c) Merasa iba dan kasih sayang terhadap pelaku. (d) Merasa nyaman ketika berinteraksi dengan pelaku. (2) Dimensi Kognisi, beberapa indikator pemaafan dari dimensi kognisi adalah (a) meninggalkan penilaian negatif terhadap pelaku. (b) Punya penjelasan nalar atas perlakuan yang menyakitkan. (c) Memiliki pandangan yang berimbang terhadap pelaku, (3) Dimensi Interpersonal, beberapa indikator pemaafan dari dimensi Interpersonal 
adalah (a) meninggalkan perilaku atau perkataan yang menyakitkan. (b) Meninggalkan keinginan balas dendam. (c) Meninggalkan perilaku acuh tak acuh. (d) Meninggalkan perilaku menghindar. (e) Meningkatkan upaya konsiliasi/rekonsiliasi hubungan. (f) Motivasi kebaikan atau kemurahan hati. (g) Musyawarah dengan pihak yang pernah menjadi pelaku.

Worthington (Seligman, 2002) mengungkapkan bahwatahapan pemaafan adalah recall, emphatize, altruistic, commit, dan hold. Lima tahapan itu biasa disebut REACH. Penjelasan atas lima tahap tefsebut adalah sebagai berikut:

a. Recall adalah mengingat kembali rasa luka itu seobyektif mungkin, tidak berpikir bahwa pelakunya adalah orang jahat, tidak merasa kasihan pada diri sendlrl.

b. Empathize atau berempati, yaitu berusaha untuk memahami sudut pahdang si pelaku. Memikirkan apa yang menyebabkan pelaku berbuat jahat.

c. Altruistic atau berupa maaf, yaitu mengenang kembali kesalahan yang telah dilakukan, lalu merasa bersalah, dan akhirnya memaafkan

d. Commit, yaitu tekad untuk niemaafkan secara terbuka atau rhenulis surat untuk memaafkan pelaku.

e. Hold, yaitu berpegang teguh pada pemaafan karena memaafkan bukanlah penghapusan melainkan merupakan perubahan pada kesan yang ditimbulkan kenangan.

Menurut Thompson, Snyder, Hoffman, Michael, dan Heather (2005), proses pemberian maaf menyangkut tiga konsep dasar pemaafan, diantaranya adalah memaafkan diri sendiri, memaafkan orang lain, dan memaafkan situasi yang terjadi.

a. Forgiveness of Self atau memaafkan diri sendiri. Tindakan ini adalah bagaimana individu memaafkan dirinya sendiri ketika terjadi suatu masalah. Bagaimana individu menyadari dan melihat bahwa dirinya melakukan kesalahan. 
b. Forgiveness of Another Person atau memaafkan kesalahan orang lain yang telah menyakiti diri sendiri karena terkadang individu memiliki keinginan untuk membalas dendam atas kesalahan yang sudah orang lain lakukan.

c. Forgiveness of Situation atau memaafkan atas keadaan yang terjadi. Maksudnya adalah individu memaafkan atas apa yang terjadi di lingkungan sekitarnya, baik itu dari lingkungan tempat tinggal maupun orang-orang yang ada di sekitarnya. Contohnya adalah terjadinya sebuah bencana yang mengakibatkan banyak kerabat yang meninggal dan rusaknya tempat tinggal.

McCullough, et al., 1998, (Dayakisni \& Hudaniah, 2009) mengemukakan determinan-determinan dari pemaafan yang dikategorikan ke dalam empat konsep:

a. Determinan yang paling dekat hubungannya dengan pemaafan adalah variabel-variabel kognisi sosial (atau afektif) yang berkaitan dengan cara berpikir dan merasa dari individu yang dilukai tentang penyerangnya dan serangan. Misalnya: empati afektif, penilaian tentang tanggung jawab dan kesalahan, niat yang dipersepsikan, beratnya serangan, dan tidak dapat dielakkannya serangan, merenungkan tentang serangan (rumination).

b. Sejumlah variabel yang taraf kedekatannya sedang dengan pemaafan yaitu tercakup di dalamnya bentuk atau sifat dari serangan itu sendiri. Jelasnya, persepsi tentang keparahan (beratnya) serangan dan akibatnya yang segera pada hubungan seharusnya mempengaruhi pemaafan (Arif, 2013), dengan serangan yang lebih berat menjadi lebih sulit memafkan. Sebagai tambahan, sejauhmana penyerang meminta maaf dan mencari pemaafan untuk serangannya itu adalah determinan lain yang berkaitan dengan pemaafan.

c. Sejumlah determinan yang moderat jauhnya adalah kualitas dari hubungan interpersonal dimana serangan itu terjadi. Variabel yang dipertimbangkan dalam hal ini sebagian besar terbentuk oleh teori interdependensi (Dayakisni \& Hudaniah, 2009), yaitu kedekatan, kepuasan dan komitmen. 
d. Determinan yang secara kausal paling jauh adalah ciri-ciri kepribadian atau proses kognitif. Misal, penelitian sebelumnya menunjukkan bahwa orang yang memafkan orang lain lebih tinggi pada faktor agreeableness dari the Big Five (Monks, Kneers, \& Haditono, 2002). Proses kepribadian ini mungkin mempengaruhi pemaafan dengan mempermudah gaya hubungan tertentu atau kecenderungan orang untuk mengalami beberapa kognisi (atribusi) atau afek (empati) dalam menanggapi suatu serangan interpersonal atau penyerang. Demikian juga, variabel seperi religiusitas memperkuat pandangan tentang pemaafan sebagai alat normatif untuk menyelesaikan pelanggaran interpersonal.

Munculnya kemampuan memaafkan dalam hubungan interpersonal merupakan hasil interaksi yang kompleks. Beberapa penelitian menunjukkan memaafkan berhubungan dengan kebahagian psikologis (Hasan, 2013), empati (McCullough et al., 1997), permohonan maaf dan perspective taking , atribusi dan penilaian kekejaman orang yang menyakiti (McCullough et al., 1997). Pada sisi lain, memaafkan merupakan terapi yang efektif dalam beberapa kasus klinis seperti pelecehan seksual dalam keluarga (Smith \& Freedman, 2020) dan aborsi (Coyle \& Enright, 1997). Hasil penelitian juga menunjukkan bahwa memaafkan tergantung pada kebahagian psikologis (Hasan, 2013) dan permohonan maaf dari pihak yang salah.

Saling memaafkan merupakan salah satu bentuk tradisi hubungan antar manusia, akan tetapi tradisi ini sering kali juga hanya merupakan ritual belaka. Dengan kata lain, perilaku tersebut dilakukan namun tidak disertai ketulusan yang sungguh-sungguh. Pada sisi lain, ada mitos yang mengatakan bahwa dengan memberi maaf maka beban psikologis yang ada akan hilang. Pada kenyataannya banyak orang yang memberi maaf kepada orang lain kemudian kecewa dengan tindakan tersebut. Hal ini terjadi karena permintaan maaf sering tidak ditindaklanjuti dengan perilaku yang konsisiten dengan permintaan maaf tersebut. (Hasan, 2013). 
Maaf-memaafkan dalam rangka memperbaiki hubungan interpersonal memerlukan tindak lanjut sesuai dengan tujuan ke masa depan, tidak berhenti pada sekedar mengatakan maaf. Zechmeister dan Romero (2002) menyatakan bahwa pemaafan sering diberikan oleh korban karena dituntut memenuhi peran sosial dalam masyarakat. Selain itu, korban bersedia memaafkan karena merasa mempunyai moral yang tinggi dan ingin mendapat penghargaan dari orang yang menyakiti. Maaf-memaafkan merupakan suatu momentum awal untuk melangkah lebih jauh ke masa depan secara bersama-sama. Kedua belah pihak seharusnya bersama-sama membina kembali suatu hubungan seperti halnya membuka lembaran baru hubungan interpersonal diantara mereka. Dalam memaafkan idealnya sikap dan perasaan negatif memang harus digantikan dengan sikap dan perasaan positif, namun pada kenyataanya hal ini tidak mudah dilakukan, apalagi secara cepat. Selalu ada persoalan psikologis di antara dua pihak yang pernah mengalami keretakan hubungan akibat suatu kesalahan. Oleh karena itu, pemaafan secara dewasa bukan berarti menghapus seluruh perasaan negatif tetapi menjadi sebuah keseimbangan perasaan (Smedes, 1984).

Keinginan untuk berbuat positif tidak berarti menghapuskan perasaan negatif yang pernah ada. Suatu keseimbangan akan dicapai jika hal yang positif dan negatif berkoeksistensi. Hal ini hanya dapat dicapai bila masing-masing individu mampu belajar menyadari bahwa setiap orang mempunyai kekurangan masingmasing. Peristiwa menyakitkan boleh jadi dilakukan oleh seorang teman tetapi mungkin dirinya juga turut berperan atas terjadinya peristiwa tersebut. Kesadaran seperti inilah yang lebih dibutuhkan daripada usaha membuat ilusi mengganti semua pengalaman negatif menjadi hal positif

\section{Metode}

Variabel yang diteliti dalam penelitian ini adalah interaksi sosial sebagai variabel tergantung dan pemaafan sebagai variabel bebasnya. Variabel pemaafan mengacu pada teori yang dikembangkan Nashori (2014), Enright (2002) dan Mc Cillough et all, (1997). Sedangkan interaksi sosial mengacu pada teori yang 
dikembangkan oleh De Vito (Sugiyo, 2005). Penelitian ini melibatkan 150 mahasiswa Program Studi Psikologi Islam Fakultas Dakwah Institut Agama Islam Negeri (IAIN) Salatiga. Responden penelitian berjenis kelamin laki-laki dan perempuan, rentang usia remaja akhir hingga memasuki dewasa awal yaitu 17- 23 tahun (Depkes R. I., 2009).

Penelitian ini menggunakan jenis penelitian kuantitatif. Azwar (2007) menyatakan bahwa penelitian dengan pendekatan kuantitatif menekankan analisisnya pada data numerikal (angka) yang diolah menggunakan metode statistika. Pendekatan kuantitatif dilakukan pada penelitian inferensial (dalam rangka pengujian hipotesis) dan menyandarkan kesimpulan hasilnya pada suatu probabilitas kesalahan penolakan hipotesis nihil. Menggunakan metode kuantitatif akan diperoleh signifikansi perbedaan kelompok atau signifikansi hubungan antar variabel. Pendekatan kuantitatif ini dianggap sesuai oleh peneliti karena penelitian ini bertujuan untuk menemukan ada atau tidaknya korelasi antara dua variabel. Dan apabila ada, sejauh mana eratnya hubungan serta berarti atau tidaknya hubungan itu.

Pemaafan diukur menggunakan skala pemaafan yang dikembangkan peneliti mengacu pada teori dan aspek pemaafan dari Nashori (2012) yang terdiri dari 3 dimensi, yaitu 1). Dimensi Emosi, 2). Dimensi Kognitif,3). Dimensi Interpersonal. Cara mengukur pemaafan menggunakan skala pemaafan yang dikembangkan peneliti berdasarkan tiga dimensi dan terdiri dari 24 item. Skor pemaafan diperoleh berdasarkan pengisian skala pemaafan oleh responden. Hasil skala pemaafan menunjukkan tingkat pemaafan pada responden sesuai dengan skor yang diperoleh, jika semakin tinggi skor skala pemaafan yang diperoleh maka tingkat pemaafan yang dimiliki seseorang semakin tinggi. Begitu juga sebaliknya, jika semakin rendah skor skala pemaafan yang diperoleh maka tingkat pemaafan seseorang semakin rendah.

Kemampuan interaksi sosial pada mahasiswa diukur menggunakan skala interaksi sosial yang dikembangkan peneliti mengacu pada teori dan aspek dari 
interaksi sosial dari De Vito (Sugiyo, 2005). Terdapat delapan Indikator dari interaksi sosial yaitu : (1) percakapan (2) saling pengertian (3) bekerjasama (4) keterbukaan (5) empati (6) memberikan dukungan atau motivasi (7) rasa positif (8) adanya kesamaan dengan orang lain. Skor kemampuan interaksi sosial diperoleh berdasarkan pengisian skala interaksi sosial oleh responden. Hasil skala interaksi sosial menunjukkan tingkat interaksi sosial pada responden sesuai dengan skor yang diperoleh, jika semakin tinggi skor skala interaksi sosial yang diperoleh maka tingkat interaksi sosial yang dimiliki seseorang semakin tinggi. Begitu juga sebaliknya, jika semakin rendah skor skala interaksi sosial yang diperoleh maka kemampuan interaksi sosial seseorang semakin rendah.

\section{Hasil}

a. Deskripsi Responden Penelitian

Gambaran mengenai responden penelitian berdasarkan data yang diperoleh adalah sebagai berikut :

Tabel 4

Deskripsi Responden Penelitian

\begin{tabular}{|c|c|c|}
\hline Usia & $\mathrm{N}$ & Prosentase \\
\hline 17 & 4 & $2,6 \%$ \\
\hline 18 & 33 & $22 \%$ \\
\hline 19 & 55 & $36,6 \%$ \\
\hline 20 & 36 & $24 \%$ \\
\hline 21 & 19 & $12,6 \%$ \\
\hline 22 & 3 & $2 \%$ \\
\hline Total & 150 & $100 \%$ \\
\hline
\end{tabular}

Berdasarkan data pada tabel 4 diketahui bahwa responden penelitian yang berusia 17 tahun sebanyak 4 orang dengan persentase 2,6\%, usia 18 tahun sebanyak 33 orang dengan persentase $22 \%$, usia 19 tahun sebanyak 55 orang dengan persentase 36,6\%, usia 20 tahun sebanyak 36 orang dengan persentase $24 \%$, usia 21 tahun sebanyak 19 orang dengan persentase 12,6\%, usia 22 tahun sebanyak 3 orang dengan persentase $2 \%$. 
Tabel selanjutnya akan menjelaskan persentase responden penelitian dalam norma persentil untuk menentukan tinggi rendahnya tingkat pemaafan dan interaksi sosial.

Tabel 5

Norma Hasil Kategori menurut Skor Percentil

\begin{tabular}{|c|c|c|c|c|}
\hline \multirow{2}{*}{ Kategorisasi } & \multicolumn{2}{|c|}{ Pemaafan } & \multicolumn{2}{c|}{ Interaksi Sosial } \\
\cline { 2 - 5 } & $\mathrm{F}$ & $\%$ & $\mathrm{~F}$ & $\%$ \\
\hline $\begin{array}{c}\text { Sangat } \\
\text { Rendah }\end{array}$ & 7 & $4,6 \%$ & 3 & $2 \%$ \\
\hline Rendah & 12 & $8 \%$ & 15 & $10 \%$ \\
\hline Sedang & 31 & $20,6 \%$ & 44 & $29,3 \%$ \\
\hline Tinggi & 75 & $50 \%$ & 60 & $40 \%$ \\
\hline $\begin{array}{c}\text { Sangat } \\
\text { Tinggi }\end{array}$ & 25 & $16,6 \%$ & 28 & $18,6 \%$ \\
\hline
\end{tabular}

Tabel 5 menunjukkan bahwa persentase pemaafan terbesar berada di kategori tinggi (75 responden) dan interaksi sosial berada di kategori tinggi (60 responden).

Tabel 6 menjelaskan terkait hasil uji hipotesis dan sumbangan efektif berdasarkan uji statistik. Berdasarkan hasil analisa data, hipotesis diuji dengan menggunakan korelasi product moment dari Pearson. Diperoleh koefisien korelasi r sebesar 0,679 dengan p 0,000 (p<0,01)

Tabel 6

Hasil Uji Hipotesis

\begin{tabular}{ccccc}
\hline Variabel & $\mathrm{N}$ & $\mathrm{R}$ & $\mathrm{r}^{2}$ & $\mathrm{P}$ \\
\hline Pemaafan*Interaksi Sosial & 0,150 & 0,679 & 0,461 & $0,000(\mathrm{p}<0,01)$ \\
\hline
\end{tabular}

Angka pada tabel 6 menunjukkan adanya korelasi yang signifikan antara variabel pemaafan dengan kemampuan interaksi sosial pada mahasiswa, 
ditunjukkan dengan nilai korelasi Pearson sebesar $p=0,000 \quad(p<0,01)$. Skor pemaafan memberikan sumbangan sebesar $46 \%$ terhadap interaksi sosial. Hasil analisis tersebut menunjukkan hubungan antara dua variabel berarah posistif, sehingga hipotesis dalam penelitian ini "diterima".

Hasil analisis selanjutnya pada tabel 7 merupakan uji anakova untuk mengetahui ada tidaknya pengaruh jenis kelamin terhadp tingkat pemaafan dan interaksi sosial . Tabel 7 menunjukkan terdapat pengaruh jenis kelamin terhadap tingkat pemaafan dan interaksi sosial. adapun sumbangan efektif variabel pemaafan terhadap kemampuan interaksi sosial ditinjau dari jenis kelamin dapat dilihat pada tabel di bawah ini.

b. Uji Anakova

Tabel 7

Hasil uji anakova variabel pemaafan dan interaksi sosial berdasarkan jenis kelamin laki-laki

\begin{tabular}{cccccc}
\hline Variabel & Jenis & $\mathrm{N}$ & $\mathrm{R}$ & $\mathrm{r}^{2}$ & $\mathrm{P}$ \\
& Kelamin & & & & \\
\hline Pemaafan*Interaksi & Laki-laki & 0,37 & 0,617 & 0,606 & $0,000(\mathrm{p}<0,01)$ \\
\hline
\end{tabular}

Tabel 8

Hasil uji anakova variabel pemaafan dan interaksi sosial berdasarkan jenis kelamin perempuan

\begin{tabular}{cccccc}
\multicolumn{6}{c}{ jenis kelamin perempuan } \\
\hline Variabel & Jenis & $\mathrm{N}$ & $\mathrm{R}$ & $\mathrm{r}^{2}$ & $\mathrm{P}$ \\
& Kelamin & & & & \\
\hline Pemaafan*Interaksi & Perempuan & 0,113 & 0,429 & 0,424 & $0,000(\mathrm{p}<0,01)$ \\
\hline
\end{tabular}

Tabel 9

Hasil Uji anakova variabel pemaafan dan intersksi sosial berdasrkan usia kurang atau sama dengan 20

\begin{tabular}{cccccc}
\hline Variabel & Usia & $\mathrm{N}$ & $\mathrm{R}$ & $\mathrm{r}^{2}$ & $\mathrm{P}$ \\
\hline Pemaafan*Interaksi & $\leq 20$ & 0,101 & 0,451 & 0,446 & $0,000(\mathrm{p}<0,01)$
\end{tabular}


tahun

Tabel 10

Hasil Uji anakova variabel pemaafan dan intersksi sosial berdasrkan usia diatas 20 tahun

\begin{tabular}{cccccc}
\hline Variabel & Usia & $\mathrm{N}$ & $\mathrm{R}$ & $\mathrm{r}^{2}$ & $\mathrm{P}$ \\
\hline Pemaafan*Interaksi & $>20$ & 0,48 & 0,509 & 0,498 & $0,000(\mathrm{p}<0,01)$ \\
& tahun & & & & \\
\hline
\end{tabular}

Hasil analisis kovarian di tabel 9 dan 10 menunjukkan terdapat perbedaan kemampuan interaksi sosial dan pemaafan ditinjau dari usia subyek penelitian. Adapun sumbangan efektif aspek pemaafan terhadp kemampuan interaksi sosial berdasarkan demografi usia di bawah 20 tahun adalah sebesar 44,6\%. Sedangkan pada usia diatas 20 tahun sebesar 49,8\%.

\section{Pembahasan}

Hasil yang diperoleh berdasarkan analisis data yang dilakukan adalah $r=$ 0,679 dan $\mathrm{p}=0(\mathrm{p}<0,01)$. Hal tersebut menunjukkan bahwa ada hubungan positif antara pemaafan dengan interaksi sosial mahasiswa. Semakin tinggi tingkat pemaafan maka semakim tinggi kemampuan interaksi sosialnya. Sebaliknya, jika seseorang memiliki tingkat pemaafan yang rendah, maka semakin rendah pula kemampuan interaksi sosialnya. Hal yang sama pentingnya dengan memberikan maaf adalah kemauan meminta maaf. Seseorang akan sulit memaafkan jika orang yang bersalah tidak minta maaf dan berupaya memperbaiki kesalahannya. Hasil penelitian (Darby \& Schlenker, 1982) menemukan bahwa meminta maaf sangat efektif dalam mengatasikonflik interpersonal, karena permintaan maaf merupakan sebuah penyataan tanggung jawab tidak bersyarat atas kesalahan dan sebuah komitmen untuk memperbaikinya. Droll (1984) menyatakan bahwa memaafkan merupakan bagian dan kemampuan seseorang melakukan komunikasi interpersonal.Seseorang yang memaafkan kesalahan pihak lain dapat dilandasi oleh komitmen yang tinggi pada relasi mereka. Ada empat alasan mengapa kualitas 
hubungan berpengaruh terhadap perilaku memaafkan dalam hubungan interpersonal. Pertama, seseorang yang mau memaafkan pada dasarnya mempunyai motivasi yang tinggi untuk menjaga hubungan. Kedua, dalam hubungan yang erat ada orientasi jangka panjang dalam menlain hubungan di antara mereka. Ketiga,dalam kualitas hubungan yang tinggi kepentingan satu orang dan kepentingan yang lainnya menyatu. Keempat, kualitas hubungan mempunyai orientasi kolektivitas yang menginginkan pihak-pihak yang terlibat untuk berperilaku yang memberikan keuntungan di antara mereka (McCullough et al., 1997).

Individu yang memiliki kemampuan interaksi sosial tinggi cenderung lebih bisa memaafkan kesalahan orang lain. Hal tersebut disebabkan oleh beberapa faktor yaitu adanya pengertian,keterbukaan dan kerjasama. Faktor-faktor itulah yang menyebabkan seseorang yang memiliki kemampuan interaksi sosial yang baik serta memiliki kemampuan untuk memaafkan kesalahan orang lain. Ketika salah satu individu dalam relasi interpersonal melakukan kesalahan maka individu yang lain akan memaafkan dengan melihat pada alasan ia mengerti dan memahami dari sudut pandang yang lain. Saat individu yang lain sudah bisa memaafkan sepenuhnya, maka relasi interpersonal dapat terjalin dengan baik dan harmonis seperti sedia kala. Dengan memaafkan individu dapat mengurangi perasaan bermusuhan dikarenakan ia membuang motivasi untuk membalas dendam dan menghindari sahabat yang melakukan kesalahan (Dayakisni \& Hudaniah, 2009). Ada banyak sekali manfaat ketika individu bisa memaafkan kesalahan orang lain. Menurut penelitian yang dilakukan Fincham, McCullough, Worthington, dan Rachel (Dayakisni \& Hudaniah, 2009) memaafkan dapat memperbaiki suatu hubungan. Suatu hubungan yang mengalami masalah akan mudah membaik ketika salah satu individu di dalamnya mau memaafkan kesalahan yang lain. Sedangkan menurut Gassin \& William (Dayakisni \& Hudaniah, 2009) memaafkan dapat mengurangi depresi, kecemasan, dan perasaan bermusuh. 
Selain itu, dari hasil penelitian diketahui bahwa terdapat perbedaan antara jenis kelamin laki-laki dan perempuan memiliki kemampuan memaafkan yang lebih tinggi di bandingkan dengan perempuan ( laki-laki $R=0,617$, Perempuan $R=$ 0,429). Hasil tersebut selaras dengan penelitian sebelumnya yang membuktikan bahwa seorang laki-laki memiliki kecenderungan yang lebih besar daripada perempuan dalam hal memaafkan karena laki-laki bisa memaafkan ketidaksetiaan pasangan selama ada hubungan timbal balik secara emosional. Saat laki-laki dikhianati atau disakiti, mereka lebih mudah memberikan maaf kepada orang yang telah menyakitinya karena laki-laki lebih bisa mengendalikan diri dan menggunakan logika atau pikiran yang mereka yakini. Laki-laki lebih memilih untuk memikirkan hal-hal masa depan dan mulai menumbuhkan kembali rasa kepercayaan terhadap sahabatnya. Sedangkan perempuan cenderung lebih sulit untuk memaafkan karena perempuan lebih menggunakan atau memanfaatkan perasaan sebagai media manipulasi untuk mengendalikan diri (Jie, Tingting, Shijin, Lulu, \& Feng, 2011).

seseorang yang tidak bersedia memaafkan memiliki implikasi yang jelas. Hal yang mungkin muncul adalah penolakan secara terang-terangan untuk memaafkan dan ditunjukkan dalam wujud perilaku sebagai manifestasi atas perasaan dan pikiran negatifnya. Namun sebagian orang lain yang tidak memaafkan menyimpan pengalaman-nya dan melakukan berbagai mekanisme pertahanan diri yang tidak membantu bahkan semakin melemahkan sumber daya dalam dirinya seperti munculnya berbagai emosi negatif, distorsi kognitif, kondisi kesehatan yang menurun, maupun perilaku yang tidak adaptif (Enright, 2002).

Pemaafan yang tulus dan benar juga akan mengandung implikasi yang berbeda dengan pemaafan yang palsu atau berpura-pura, baik disadari maupun tidak disadari. Inilah sebabnya mengapa isu mengenai mekanisme pertahanan diri muncul dalam proses memaafkan, selain alasan bahwa untuk menjalani proses memaafkan itu sendiri bukan suatu hal yang mudah. Seseorang yang sudah memulai proses memaafkan sangat mungkin sekali kembali memulai prosesnya 
dari awal atau bahkan menjadi tidak bersedia memaafkan karena merasa belum benar-benar siap (Enright, 2002).

Berdasarkan hasil penelitian, diketahui bahwa pemaafan memiliki kontribusi sebesar 60,6 \% terhadap variabel interaksi sosial. Angka kontribusi ini masuk kategori Large Effect Size Cohen (1992) yang artinya pemaafan memberikan kontribusi yang signifikan terhadap kemampuan interaksi sosial. Faktor lain masih memiliki kontribusi sebesar 54\% yang mempengaruhi kemampuan interaksi sosial seseorang. Temuan lain dari hasil penelitian adalah terdapat perbedaan kemampuan memafkan dan interaksi sosial ditinjau dari demografi usia. Analisis ini mengelompokkan usia subyek penelitian $\leq 20$ tahun dan $>20$ tahun. Hasil analisis menunjukkan usia $>20$ tahun memiliki kemampuan memaafkan yang lebih tinggi dibandingkan usia $\leq 20$ tahun . hal ini selaras dengan apa yang disampaikan oleh Nashori (2014) bahwa semakin dewasa seseorang maka akan semakin meningkatkan kematangan emosi, kepedulian dan empati. Hal ini sejalan dengan hasil analisis data, semakin dewasa usia responden, maka aspek pemaafan yang dominan adalah emosi yang menunjukkan sikap penuh kasih sayang dan kemampuan mengontrol emosi dengan baik. Serta aspek interpersonal yaitu lebih sabar dan meningglkan perkataan dan perilaku yang kurang menyenangkan. Hal ini juga sejalan dengan hasil penelitian yang dilakukan oleh Radhitia dan Ilham (2012) menyebutkan bahwa terdapat hubungan yang signifikan antara kematangan diri dan kecenderungan memaafkan.

\section{Simpulan}

Berdasarkan hasil analisis data dan pembahasan dapat disimpulkan bahwa tinggi rendahnya kemampuan interaksi sosial dapat dijelaskan oleh tingkat pemaafan yang dimiliki oleh seseorang. Hasil analisis menjelaskan jika semakin tinggi tingkat pemaafan mahasiswa maka semakin tinggi kemampuan interaksi 
sosial yang dimiliki mahasiwa tersebut. Hasil ini menunjukkan jika kemampuan memaafkan mahasiswa juga dipengaruhi oleh faktor usia dan jenis kelamin.

\section{Saran}

Mahasiswa perlu meningkatkan karakter pemaaf, sebab memiliki dampak baik bagi kehidupan, salah satunya adalah mningkatkan kemampuan interaksi sosial pada diri mahasiswa. Aktivitas mahasiswa yang setiap hari melakukan interaksi sosial dengan orang lain baik dengan teman sebaya, dengan dosen ataupun dengan lingkungan tempat tinggal memerlukan karakter pemaaf, sehingga segala konflik atau emosi negatif seperti rasa marah, kecewa, sakit hati akan dapat segera diselesaikan. Memiliki karakter pemaaf juga akan memunculkan potensi-potensi positif dari diri mahasiswa tersebut. 


\section{DAFTAR PUSTAKA}

Abdulsyani. (1994). Sosiologi Skematika, Teori, dan Terapan. Jakarta: Bumi Aksara.

Arif, T. A. (2013). Komitmen dengan Pemaafan dalam hubungan persahabatan. Jurnal Online Psikologi, 1(2).

Azwar, S. (2007). Metode Penelitian. Yogyakarta: Pustaka Pelajar.

Basrowi. (2005). Pengantar sosiologi. Bogor: Penerbit Ghalia.

Burney, D. M., \& Kromrey, J. (2001). Initial development and score validation of the adolescent anger rating scale. Educational and Psychological Measurement, 61(3), 446-460.

Coyle, C. T., \& Enright, R. D. (1997). Forgiveness Intervention With Postabortion Men. Journal Of Consulting and Clinical Psychology, 65 (6), 1042-1046.

Darby, B. W., \& Schlenker, B. R. (1982). Children Reactions to Apologies. Journal of Personality and Social Psychology, 43 (4), 742-753.

Dayakisni, T., \& Hudaniah. (2009). Psikologi sosial. In UMM Press. Malang.

Depkes R. I. (2009). Profil kesehatan Indonesia. Depkes RI.

Detik.com. (2016). Mahasiswa Bunuh Teman Indekosnya Di Bandung Karena Sakit Hati. Retrieved July 12, 2020, from Detik.com website: http://m.detik.com/news/berita-jawa-barat/3186317/mahasiswa-bunuhteman-indekosnya-di-bandung-karena-sakit-hati,htm,

Droll, D. M. (1984). Forgiveness: Theory and Research. University of Nevada-Reno.

Enright, R. D. (2002). Forgiveness is a choice, a step-by-step process for resolving anger and restoring hope. Washington: APA.

Fincham, F. D., Beach, S. R., \& Davila, J. (2004). Forgiveness and Conflict Resolution in Marriage. Journal of Family Psychology, 18 (2).

Gani, H. A. (2011). Forgiveness Therapy. Yogyakarta: Kanisius.

Hasan, A. B. P. (2013). Pemaafan sebagai Variabel Moderator pada Pengaruh Religiusitas dengan Agresi Relasional di Kalangan Mahasiswa Universitas Berbasis Nilai-nilai Islam. Jurnal AL-AZHAR INDONESIA SERI HUMANIORA, 2 (1).

Jie, W., Tingting, M., Shijin, S., Lulu, Y., \& Feng, W. (2011). Higher ruminative tendency of anger in trust-forgiveness young adults. International Conference on Social Science and Humanity. Singapore: IACSIT Press.

McCullough, M. ., Wortington, E. L., \& Rachal, K. C. (1997). Interpersonal orgiving in Close Relationships. Journal of Personality and Social Psychology, 73 (2), 321336. 
Monks, F. ., Kneers, A., \& Haditono, S. (2002). Psikologi Perkembangan. Yogyakarta: Gajah Mada University Press.

Nashori, F. (2012). Pemaafan pada Etnis Jawa. Bandung: Unpad Press.

Nashori, F. (2014). Psikologi pemaafan. Yogyakarta: Safiria Insania Press.

Nashori, H. F. (2008). Psikologi sosial islami. Bandung: Refika Aditama.

Paramitasari, R., \& Alfian, I. N. (2012). Hubungan antara Kematangan. Emosi dengan Kecenderungan Memaafkan pada Remaja Akhir. Jurnal Psikologi Pendidikan Dan Perkembangan, 1, No.22.

Rostiana. (1999). Diskripsi dan dinamika koflik pada boundary role person. Jurnal Ilmiah Arkhe, 4 (7).

Seligman, M. (2002). Authentic happiness: Using the new positive psychology to realize your potential for lasting fulfill-ment. New York: Free Press.

Smedes, L. B. (1984). Forgive and Forget: Healing The Hurts We Don't Deserve. San Francisco: Harpersan.

Smith, A. W., \& Freedman, D. O. (2020). Isolation, quarantine, social distancing and community containment: pivotal role for old-style public health measures in the novel coronavirus (2019-nCoV) outbreak. Journal of Travel Medicine, 27 (2).

Sugiyo. (2005). Komunikasi Antarpribadi. Semarang: UNNES Press.

Thompson, L. Y., Snyder, C. R., Hoffman, L., Michael, S. T., Rasmussen, H. N., Billings, L. S., ... Robert, D. E. (2005). Dispositional forgiveness of self, other, and situation. Journal of Personality, 73 (2), 313-359.

Walgito, B. (2003). Psikologi Sosial. Yogyakarta: Andi Offset.

Worthington, E. L., \& Scherer, M. (2004). Forgiveness is an emotion-focused coping strategy that can reduce health risks and promote health resilience: theory, review, and hypotheses. Psychology \& Health, 19(3), 385-405. https://doi.org/https://doi. org/10. 1080/0887044042000196674 